\title{
Adsorption Characteristics of Oxytetracycline by Different Fractions of the Organic Matter from Humus Soil: Insight from Internal Structure and Composition
}

\author{
Mengya Luo, Shengke Yang *, Siqi Shen and Yu Li \\ Key Laboratory of Subsurface Hydrology and Ecological Effects in Arid Region (Chang'an University), \\ Ministry of Education, School of Water and Environment, Chang'an University, Xi'an 710054, China; \\ 2018229049@chd.edu.cn (M.L.); 2018229032@chd.edu.cn (S.S.); 2018229051@chd.edu.cn (Y.L.) \\ * Correspondence: yskfxh@chd.edu.cn; Tel.: +86-135-7200-5085
}

Received: 8 January 2020; Accepted: 29 January 2020; Published: 1 February 2020

\begin{abstract}
For minimizing the transport of antibiotics to groundwater, the migration of antibiotics in soils should be investigated. Soil organic matter can affect the migration of antibiotics. To date, the influence of aromatics and aliphatic content of organic matter on the adsorption of antibiotics has been controversial. To better understand the reaction mechanism of soil organic matter with antibiotics, this study investigated the adsorption of oxytetracycline (OTC) by humus soils (HOS) and their fractions. HOS were sequentially fractionated into four organic fractions, including the removal of dissolved organic matter (HRDOM), removal of minerals (HRM), removal of free fat (HRLF), and nonhydrolyzable organic carbon (HNHC). Moreover, batch experiments revealed that adsorption capacity was ordered by HNHC $>$ HOS $>$ HRDOM $>$ HRLF $>$ HRM. SEM images and $\mathrm{N}_{2}$ adsorption/desorption isotherms indicate that adsorption capacity is independent of the external structure. However, adsorption capacity is related to the internal structure and composition. Combination analysis with elemental composition and infrared spectroscopy showed that the adsorption capacity of HRM, HRLF, and HNHC had a good positive correlation with aromaticity, but a negative correlation with polarity and hydrophilicity. Additionally, the rule of binding affinity between OTC and functional groups with different properties was summarized as aromatic $>$ polarity $>$ hydrophilic.
\end{abstract}

Keywords: Humus; organic matter fractions; oxytetracycline; adsorption

\section{Introduction}

Antibiotics are not only used in human medicine for treatment, but also widely used in livestock feed in recent years [1]. Antibiotics have been extensively detected in soil, overland runoff, underground water, and sediment [2]. Oxytetracycline (OTC), belonging to the tetracyclines class of antibiotics, is used in the livestock and poultry industry worldwide owing to its high quality and low price [3]. Since solid retention time is commonly one order of magnitude higher than hydraulic retention time, certain antibiotics and degradation products might accumulate in the soil, leading to higher soil concentrations than in raw sewage [4-6]. It was reported that OTC were detected most frequently in farmland soil of Canada and Britain, at concentrations as high as $513 \mu \mathrm{g} / \mathrm{kg}$ and $1691 \mu \mathrm{g} / \mathrm{kg}[6,7]$ respectively. The concentration of OTC in the sediments around an aquaculture plant in China was as high as $300 \mathrm{mg} / \mathrm{kg}$ [8]. Antibiotics can not only damage the soil environment, but also affect human health [9-12]. More importantly, antibiotics are moved with soil water to enter the underground water and cause pollution. Thus, understanding the migration of antibiotics in soil has significance for the protection of groundwater. 
The fate of antibiotics in soil are mainly controlled by the adsorption/desorption function of soil. The adsorption behavior of antibiotics is further affected by clay minerals, metal oxides, and organic matter in soil [13-15]. Although there is little organic matter in soil, it can strongly affect the fate of antibiotics in soil $[15,16]$. Soil is negatively charged owing to organic matter surface contained polar functional groups, for instance, hydroxyl, carbonyl, and carboxyl. The polar functional groups of antibiotics can be adsorbed to the surface of the soil through electrostatic interaction [17], hydrogen bond [18], synergistic interaction, and complexation mechanism [19]. The influences of organic matter have been extensively reported during the adsorption/desorption process of antibiotics in soil. Many have found that there is a simple positive relationship between the content of soil organic matter and adsorption capacity [20,21]. However, Pils et al. [22] found that some soil organic matter could cover up adsorption points, leading to reduce the absorption of antibiotics in the soil. Therefore, such a simple positive correlation denotes a lack of rationality. In summary, the previous studies suggested that organic matter could affect the migration of antibiotics in soil. However, there remains controversy about the influence of organic matter on antibiotic adsorption at present. Further studies on accurate feature and mechanism of soil organic matter adsorption/desorption for antibiotics are necessary.

According to solubility, Weber et al. [23] separated soil organic matter operationally into fulvic acid (FA), humic acid (HA), and humin (HM). The adsorption capacity of hydrophobic organic pollutants are order: FA $<$ HA $<$ HM [24]. However, the affinity of polycyclic aromatic hydrocarbons for HM is lower than that for HA [25]. Sun et al. [26] found that nonhydrolyzable organic carbon (NHC) was separated into kerogen graphitic $(\mathrm{KC})$ and black carbon $(\mathrm{BC})$. The adsorption capacity of Phenanthrene (Phen) by different fractions of organic matter are: $\mathrm{NHC} \approx \mathrm{BC}>\mathrm{KC}$. Ran et al. [27] further found the adsorption capacity of Phen by NHC fraction is negative with respect to aromatic carbon content. However, Jin et al. [28] found aromatic domains of NHCs acted as p-acceptors to promote the adsorption of Phen. Obviously, for hydrophobic organic pollutants only, the adsorption mechanism is complex. OTC as hydrophilic organics pollutants contain polar functional groups (e.g., - $\mathrm{OH}-\mathrm{CONH}$ and $-\mathrm{NH}\left(\mathrm{CH}_{3}\right)_{2}$ ), which make the adsorption process more complex than hydrophobic organic pollutants, but must have its specific regular. It is necessary to explore different types of regular pollutant adsorption by different fractions of organic matter. Besides the property of antibiotics and the content of soil organic matter, the source, fractions, and functional groups of organic matter can affect adsorption. For understanding the reaction and mechanisms between organic compounds and different fractions of matter organic, the roles of composition and internal fine structure in their adsorption should be further investigated.

It should be emphasized that the composition and structure of organic matter differs greatly depending on the soil type [29]. Humus soil (HOS) is a kind of geologically young soil, formed by dead branches and leaves after long term decay fermentation. Compared to the sedimentary and peat soils studied previously, the of HOS structure is loose and porous and contains carboxyl, hydroxyl, and some other functional groups, with a more representative and typical adsorption of pollutants [30,31]. Therefore, the purpose of this study was as follows: (1) HOS was sequentially divided into the removal of dissolved organic matter (HRDOM), removal of minerals (HRM), removal of free fat (HRLF), and nonhydrolyzable organic carbon (HNHC) to evaluate different fractions adsorption characteristics and mechanisms on OTC. (2) Compare and analyze the adsorption relationship of OTC among different dissolve organic matter (DOM) coming from different soils. (3) Reveal the effect of functional groups of different fractions on OTC adsorption.

\section{Materials and Methods}

\subsection{Extraction Treatment of Sample}

The HOS (original sample) was collected from the $5-15 \mathrm{~cm}$ below the ground under the surface of the shrub along the Weihe river basin ( $\left.34^{\circ} 23^{\prime} 41.86^{\prime \prime} \mathrm{N}, 108^{\circ} 52^{\prime} 38.99^{\prime \prime} \mathrm{E}\right)$. After removing the impurities, the HOS was naturally dried in the dark. Then was pestle through a sieve ( 80 mesh). It was 
sealed and saved at $4{ }^{\circ} \mathrm{C}$ before used (all the samples were detected without OTC). Figure 1 shows brief steps [31-33].

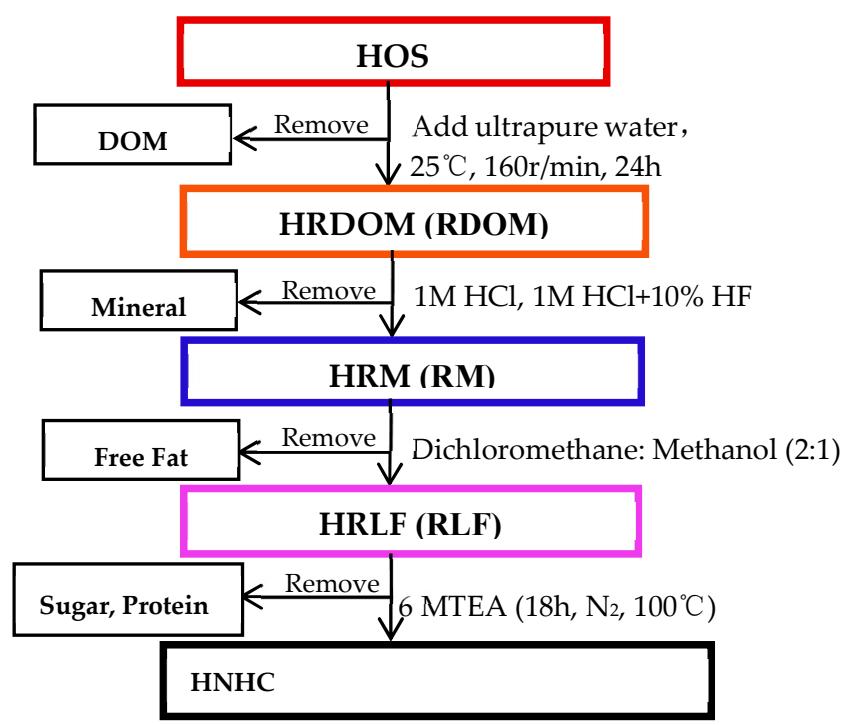

Figure 1. Extraction treatment of the organic matter of humus soil.

The first step was to obtain HRDOM fraction: $30 \mathrm{~g}$ of HOS and $300 \mathrm{ml}$ of ultrapure water were shaken on a shaker for $24 \mathrm{~h}$ in an Erlenmeyer flask, and then the solution was centrifuged. The supernatant was soil dissolved organic matter (DOM), which was saved in the dark at $4{ }^{\circ} \mathrm{C}$ after filtering through a $0.45 \mu \mathrm{m}$ filter. The centrifuged solid was HRDOM fractions after drying.

The second step was to obtain HRM fraction: Firstly, the HRDOM fraction was dissolved in $1 \mathrm{M} \mathrm{HCl}$, shaken for one day, and centrifuged for 30 minutes to remove carbonate. To remove the silicate, the solid after centrifuge was shaken with a $10 \%$ mixture of $1 \mathrm{~m} \mathrm{HCl}$ and $\mathrm{HF}$ for 4 days. Finally, the solid was HRM fraction after centrifuging again and drying.

The third step was to obtain HRLF fraction: The HRM fraction was extracted under ultrasonic conditions for 15 minutes, and the supernatant was removed by centrifugation. After repeated 5 times, the solid portion obtained was the HRLF fraction. The extract solution was consisted of dichloromethane and methanol (2:1, V/V).

The fourth step was to obtain HNHC fraction: The HRLF fraction was successively hydrolyzed with $2 \mathrm{M}$ trifluoroacetic acid, $4 \mathrm{M}$ and $6 \mathrm{MTFA}$ and $6 \mathrm{M} \mathrm{HCl}$ in Teflon furnace at $100^{\circ} \mathrm{C}$ for one day. Then, the supernatant was removed after centrifugation. The solids are then washed with ultrapure water to neutrality, which is the HNHC fraction. Fill with nitrogen for not less than 5 minutes before each hydrolyze.

All shaken parameters were $160 \mathrm{rpm}$ for $24 \mathrm{~h}$ and centrifugation parameters were $6000 \mathrm{rpm}$ for $30 \mathrm{~min}$. All sample were dried at $50{ }^{\circ} \mathrm{C}$ before use. Table 1 shows the total organic carbon (TOC) content and $\mathrm{pH}$ values.

Table 1. TOC and $\mathrm{pH}$ of different fractions.

\begin{tabular}{cccccc}
\hline Sample & HOS & HRDOM & HRM & HRLF & HNHC \\
\hline TOC $(\%)$ & 28.956 & 24.060 & 47.425 & 48.389 & 49.321 \\
pH & 5.86 & 6.91 & 7.03 & 6.81 & 7.02 \\
\hline
\end{tabular}

\subsection{Batch Experiment}

The batch experiments followed the Organization for Economic Cooperation and Development method [34]. Under neutral conditions, $0.05 \mathrm{~g}$ of different fractions and $5 \mathrm{~mL}$ of $10.0 \mathrm{mg} / \mathrm{L} \mathrm{OTC}$ solution 
at $30{ }^{\circ} \mathrm{C}$ which shaking at $160 \mathrm{rpm}$ for one day in the dark. The kinetic data were obtained at 2, 4, 8, $12,20,24,28,36$ and $48 \mathrm{~h}$. For adsorption isotherm and thermodynamic experiments, OTC initial concentrations were between $5 \mathrm{mg} / \mathrm{L}$ and $25 \mathrm{mg} / \mathrm{L}$, the OTC solution temperatures were $20^{\circ} \mathrm{C}, 30^{\circ} \mathrm{C}$, and $40{ }^{\circ} \mathrm{C}$, respectively. The samples were filtered through a $0.45-\mu \mathrm{m}$ filter before ultra-performance liquid chromatography (UPLC). All of the experiments were performed in triplicates.

Batch experiments were performed in the $\mathrm{pH}$ range of 2-10 for explore the influence of $\mathrm{pH}$ on OTC adsorption. To explore the influence of DOM types on OTC adsorption, $1 \mathrm{~mL}$ exogenous DOM from decay plant (PDOM) and chicken manure (MDOM) were added into the removal of DOM of humus and sediment soil for batch adsorption experiments. PDOM and MDOM extraction methods were consistent with humus soil.

\subsection{Sample Analysis}

OTC in solution was detected by UPLC. The chromatographic column was ACQUITY UPLC BEH $\mathrm{C} 18$ column $(2.1 \times 150 \mathrm{~mm}, 1.7 \mu \mathrm{m}$ particles $)$. The column temperature was $40^{\circ} \mathrm{C}$. Injection volume was $5 \mu \mathrm{L}$ and flow rate was $0.2 \mathrm{~mL} / \mathrm{min}$. Mobile phase composition was methanol: water $=60: 40(\mathrm{v} / \mathrm{v})$. The equations of adsorption models of kinetics and isotherm were employed to fit the experimental data, as shown in Table 2 [35,36].

Table 2. The equations of adsorption models of kinetics and isotherm.

\begin{tabular}{|c|c|c|}
\hline Model & Equation & Parameters \\
\hline Pseudo-first-order kinetic & $Q_{t}=Q_{e}\left(1-e^{-K_{1} t}\right)$ & $\begin{array}{c}Q_{t}=\text { quantity of OTC adsorbed at any } \\
\text { time } \mathrm{t}(\mathrm{mg} / \mathrm{kg}) \\
Q_{e}=\text { quantity of OTC } \text { adsorbed at } \\
\text { equilibrium }(\mathrm{mg} / \mathrm{kg})\end{array}$ \\
\hline pseudo-second-order kinetic & $Q_{t}=\frac{K_{2} Q_{e}^{2} t}{1+K_{2} Q_{e} t}$ & $\begin{array}{c}k_{1}=\text { pseudo-first-order rate constant } \\
(1 / \mathrm{h}) \\
k_{2}=\text { pseudo-second-order rate } \\
\text { constant }(\mathrm{kg} / \mathrm{mg} \mathrm{h})\end{array}$ \\
\hline Langmuir adsorption isotherm & $Q_{e}=\frac{Q_{\max } K_{L} C_{e}}{1+K_{L} C_{e}}$ & $\begin{array}{c}C_{e}=\text { OTC concentration of solution at } \\
\text { equilibrium }(\mathrm{mg} / \mathrm{L}) \\
Q_{\text {max }}=\begin{array}{c}\text { maximum adsorbed capacity } \\
(\mathrm{mg} / \mathrm{kg})\end{array} \\
K_{L}=\begin{array}{c}\text { Langmuir adsorption isotherm } \\
\text { constant }(\mathrm{L} / \mathrm{mg})\end{array}\end{array}$ \\
\hline Freundlich adsorption isotherm & $Q_{e}=K_{F} C_{e}^{\frac{1}{n}}$ & $\begin{array}{c}k_{F}=\text { Freundlich adsorption coefficient } \\
\left((\mathrm{mg} / \mathrm{kg})(\mathrm{L} / \mathrm{mg})^{1 / \mathrm{n}}\right) \\
1 / n=\text { Freundlich index }\end{array}$ \\
\hline
\end{tabular}

\subsection{Characterization of Different Fractions}

Quanta 200 scanning electron microscopy was used to observe the morphology of different fractions. The pore-size distributions and specific surface areas were analyzed volumetric system (ASAP 2460, Micromeritics, America) through the nitrogen adsorption/desorption isotherms. Vario ELIII elemental analyzer was used analysis elemental $(\mathrm{C}, \mathrm{H}, \mathrm{N})$. The fluorescence spectra (F-7000; Hitachi, Japan) of DOM were recorded. The excitation and emission wavelengths (Ex and Em) ranged from 220 to $600 \mathrm{~nm}$ and 250 to $600 \mathrm{~nm}$, respectively. The scan rate was $1200 \mathrm{~nm} / \mathrm{min}$. The different fractions were characterized by Tensor 27 infrared spectroscopy. The Elementar Vario TOC was analyzed TOC.

\subsection{Quality Assurance and Control}

The calibration curve was prepared by more than seven standard solutions in the linear range. The linear range of OTC test was $1-100 \mathrm{mg} / \mathrm{L}$. The detection limits of quantification were 
0.051-0.057 mg/L, while relative deviations were $2.6 \%-10.8 \%$. Recoveries of the OTC were determined in the range of $79 \%$ and $113 \%$. OTC were not detected in the blank sample, so the data were reliable.

\section{Results and Discussion}

\subsection{Adsorption Studies}

\subsubsection{Adsorption Kinetic}

As shown in Figure 2, the adsorption rate of HRM, HRLF, and HNHC were significantly higher than that of HOS and HRDOM. This may be due to the presence of DOM and inorganic minerals so that further adsorption requires greater activation energy, and the adsorption rate becomes slow. However, HRM, HRLF, and HNHC are removed of minerals, lipids, carbohydrates, and other pollutants which can quickly reach the adsorption equilibrium. The specific amounts of five fractions were calculated as the equation listed below:

$$
q_{t}=\left(\frac{C_{0}-C_{t}}{m}\right) V
$$

where $q_{t}(\mathrm{mg} / \mathrm{kg})$ is the quantity of OTC adsorbing onto different fractions at a predetermined time, $C_{t}$ $(\mathrm{mg} / \mathrm{L})$ is the instantaneous concentration of OTC in solution at time $\mathrm{t}(\mathrm{h})$.

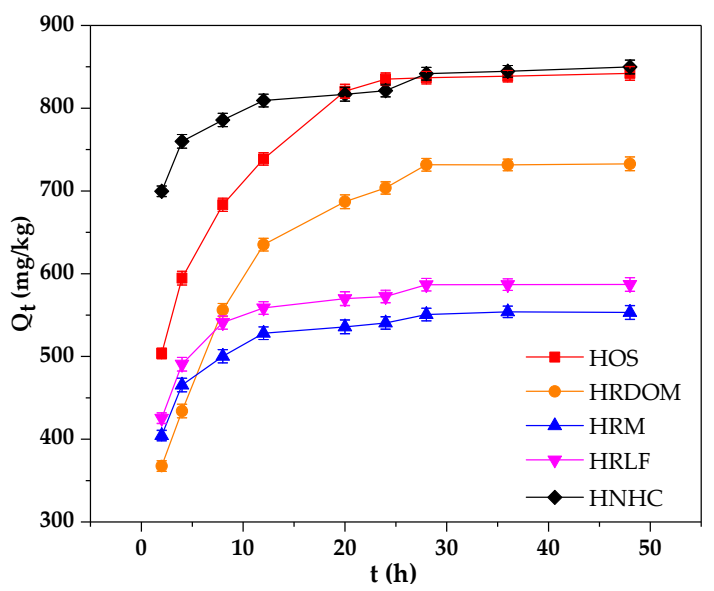

Figure 2. Adsorption characteristics of OTC by different fractions.

The corresponding fitting parameters are listed in Table 3. The smaller the residual sum of squares (RSS/dof), the better the model fits. Hence, the equilibrium adsorption capacity (Qe, cal) of the pseudo-second-order kinetics model is close to the actual equilibrium adsorption capacity (Qe, exp). The K values of adsorption by HRM, HRLF, and HNHC are significantly larger than those of HOS and HRDOM, which may be related to the microstructure of different fractions.

Table 3. The adsorption kinetics model fitted parameters.

\begin{tabular}{ccccccccccc}
\hline \multirow{2}{*}{ Samples } & $\begin{array}{c}\text { Qe,exp } \\
\mathbf{( m g / k g )}\end{array}$ & \multicolumn{3}{c}{ Pseudo-First-Order Model } & \multicolumn{3}{c}{ Pseudo-Second-Order Model } \\
\cline { 3 - 10 } & & $\mathbf{R}^{\mathbf{2}}$ & $\begin{array}{c}\mathbf{K}_{\mathbf{1}} \\
\mathbf{( 1 / h )}\end{array}$ & $\begin{array}{c}\mathbf{Q e , c a l} \\
\mathbf{( m g / k g )}\end{array}$ & $\mathbf{R S S} / \mathbf{d o f}$ & $\mathbf{R}^{\mathbf{2}}$ & $\begin{array}{c}\mathbf{K}_{\mathbf{2}} \\
\mathbf{( k g} / \mathbf{m g} \cdot \mathbf{h})\end{array}$ & $\begin{array}{c}\text { Qe,cal } \\
\mathbf{( m g / k g )}\end{array}$ & $\mathbf{R S S / d o f}$ \\
\hline HOS & 842.10 & 0.8182 & 0.4020 & 807.58 & 381.18 & 0.9648 & 0.0007 & 872.29 & 73.73 \\
HRDOM & 732.78 & 0.8876 & 0.2697 & 704.68 & 281.80 & 0.9748 & 0.0005 & 779.05 & 63.09 \\
HRM & 553.14 & 0.8566 & 0.6527 & 536.78 & 51.52 & 0.9909 & 0.0022 & 561.32 & 3.26 \\
HRLF & 587.04 & 0.8817 & 0.6360 & 570.89 & 50.25 & 0.9952 & 0.0020 & 597.27 & 2.02 \\
HNHC & 849.83 & 0.7613 & 0.9189 & 821.57 & 78.81 & 0.9575 & 0.0027 & 844.86 & 14.03 \\
\hline
\end{tabular}




\subsubsection{Adsorption Isotherms}

The non-linear fitting of Langmuir and Freundlich model to isothermal adsorption data is shown in Figure 3 and Table 4. All samples are fitted well with the Freundlich model by considering lower Akaike's information criterion (AICc) [37]. The degree of nonlinearity and difficulty of adsorption both have negative correlations with the value of $1 / \mathrm{n}$. The values of $1 / \mathrm{n}$ range from 0.37 to 0.63 , which indicate an obvious non-linearity process for the OTC adsorption by different fractions in humus soil. HNHC is speculated to be the most likely component for OTC adsorption, followed by HOS, HRDOM, HRLF, and HRM. In addition, generally, the adsorption capacity has a positive value of $\mathrm{K}_{\mathrm{F}}$ [38]. Therefore, the adsorption capacity of each fraction is ordered: HNHC $>$ HOS $>$ HRDOM $>$ HRLF > HRM.

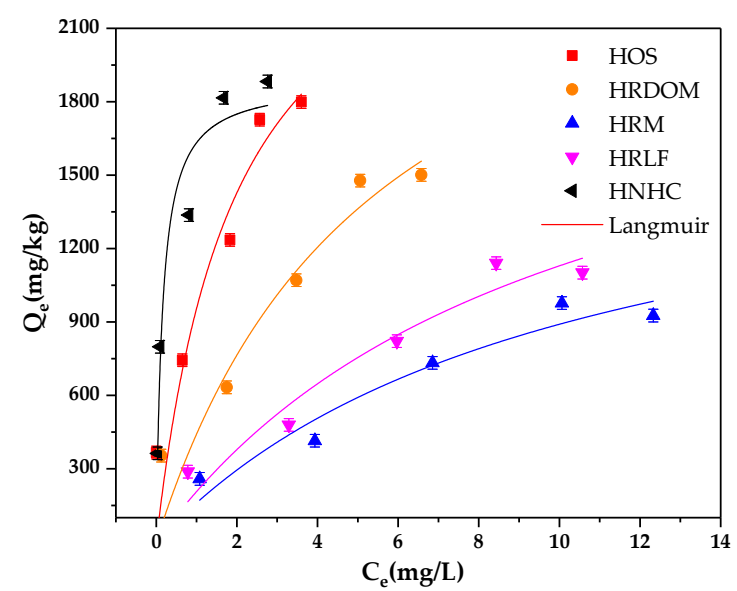

(a)

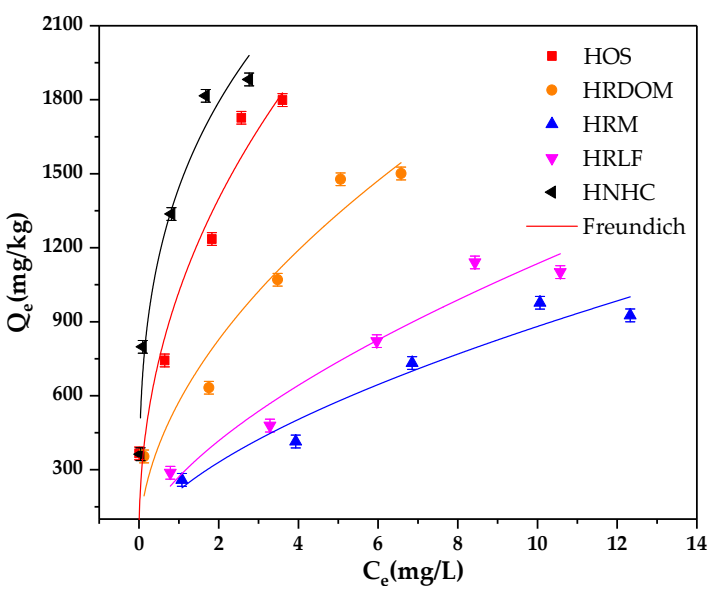

(b)

Figure 3. The fitted adsorption isotherms of OTC by different fractions: (a) Langmuir model; (b) Freundlich model.

Table 4. The fitted parameters for Langmuir isotherm model and Freundlich isotherm model.

\begin{tabular}{|c|c|c|c|c|c|c|c|c|}
\hline \multirow[b]{2}{*}{ Samples } & \multicolumn{4}{|c|}{ Langmuir model } & \multicolumn{4}{|c|}{ Freundlich Model } \\
\hline & $\begin{array}{c}Q_{\mathrm{m}} \\
(\mathrm{mg} / \mathrm{kg})\end{array}$ & $\begin{array}{c}\mathrm{K}_{\mathrm{L}} \\
(\mathrm{L} / \mathrm{mg})\end{array}$ & $\mathrm{AIC}_{\mathrm{c}}$ & RSS/dof & $\begin{array}{c}\mathrm{K}_{\mathrm{F}}(\mathrm{mg} / \mathrm{kg}) \\
(\mathrm{L} / \mathrm{mg})\end{array}$ & $1 / n$ & $\mathrm{AIC}_{\mathrm{c}}$ & RSS/dof \\
\hline HOS & 2697.61 & 0.5906 & 34.86 & 721.41 & 1061.04 & 0.4469 & 31.46 & 365.88 \\
\hline HRDOM & 2576.05 & 0.2231 & 34.28 & 642.38 & 600.81 & 0.4947 & 31.31 & 355.11 \\
\hline HRM & 1687.53 & 0.0918 & 26.00 & 122.61 & 218.91 & 0.6364 & 25.02 & 100.83 \\
\hline HRLF & 2377.73 & 0.1062 & 27.83 & 176.73 & 263.77 & 0.5940 & 25.99 & 122.54 \\
\hline HNHC & 2737.76 & 0.6032 & 30.58 & 306.79 & 1083.64 & 0.3798 & 30.23 & 285.59 \\
\hline
\end{tabular}

\subsubsection{Adsorption Thermodynamic}

The thermodynamic characteristics of OTC adsorption can help to further understand the trend and extent of OTC adsorption by different fractions. The thermodynamic parameters can be calculated as following equations:

$$
\begin{aligned}
\Delta G & =-R T \ln K_{0}, \\
\ln K_{0} & =-\frac{\Delta H}{R T}+\frac{\Delta S}{R}
\end{aligned}
$$

where $\Delta G, \Delta H$ and $\Delta S$ are standard free energy change $(\mathrm{kJ} / \mathrm{mol})$, standard enthalpy change $(\mathrm{kJ} / \mathrm{mol})$, and standard entropy changes $(\mathrm{J} / \mathrm{mol} \mathrm{k})$, respectively. $R$ is the universal gas constant $(8.314 \mathrm{~J} / \mathrm{mol} \mathrm{k})$ and $T$ is the temperature $\left({ }^{\circ} \mathrm{C}\right) . K_{0}$ is the thermodynamic equilibrium constant. The parameters are listed in Table 5. The values of $\Delta G$ are range from -9.67 to $-22.33 \mathrm{~kJ} /$ means that the adsorption of 
OTC is spontaneous by different fractions at different temperatures. The $\Delta G$ values are increased with removal of DOM. The presence of DOM can prevent macromolecules from occupying adsorption sites on the soil surface. In addition, studies have shown the value of $\Delta \mathrm{G}$ is $-20 \sim 0 \mathrm{~kJ} / \mathrm{mol}$ meaning physical adsorption. The chemical adsorption is $-80 \sim-400 \mathrm{~kJ} / \mathrm{mol}$ [39]. However, the value of $\Delta H$ between 12.98 to $99.26 \mathrm{~kJ} / \mathrm{mol}$ suggests that the adsorption of OTC by different fractions is endothermic. Increasing the temperature can promote adsorption. More heat is needed for chemical adsorption than physical adsorption, so the adsorption of OTC by different fractions is not simple physical adsorption. The value of $\triangle H$ of HRDOM, HRM, and HRLF are lower than HOS and HNHC, which implies that there is weak bonding between the OTC and HRDOM, HRM and HRLF. The positive $\Delta S$ value indicates that the adsorption is an entropy increasing reaction, which means it is likely that the adsorption of OTC may occur in the different fractions of an internal structure [40].

Table 5. The parameters of adsorption thermodynamics.

\begin{tabular}{|c|c|c|c|c|c|}
\hline Samples & $\mathrm{T}\left({ }^{\circ} \mathrm{C}\right)$ & $\ln K_{0}$ & $\Delta G(\mathrm{KJ} / \mathrm{mol})$ & $\Delta H(\mathrm{KJ} / \mathrm{mol})$ & $\Delta S(\mathrm{KJ} / \mathrm{mol})$ \\
\hline \multirow{3}{*}{ HOS } & 20 & 5.26 & -12.81 & \multirow{3}{*}{91.86} & \multirow{3}{*}{0.3572} \\
\hline & 30 & 6.49 & -16.90 & & \\
\hline & 40 & 7.67 & -19.33 & & \\
\hline \multirow{3}{*}{ HRDOM } & 20 & 4.84 & -11.80 & \multirow{3}{*}{12.98} & \multirow{3}{*}{0.0871} \\
\hline & 30 & 5.94 & -14.96 & & \\
\hline & 40 & 6.16 & -16.03 & & \\
\hline \multirow{3}{*}{ HRM } & 20 & 3.97 & -9.67 & \multirow{3}{*}{36.40} & \multirow{3}{*}{0.1578} \\
\hline & 30 & 4.68 & -11.79 & & \\
\hline & 40 & 4.92 & -12.80 & & \\
\hline \multirow{3}{*}{ HRLF } & 20 & 4.46 & -10.86 & \multirow{3}{*}{30.61} & \multirow{3}{*}{0.1419} \\
\hline & 30 & 5.01 & -12.62 & & \\
\hline & 40 & 5.26 & -13.69 & & \\
\hline \multirow{3}{*}{ HNHC } & 20 & 5.96 & -14.52 & \multirow{3}{*}{99.26} & \multirow{3}{*}{0.3863} \\
\hline & 30 & 6.57 & -16.55 & & \\
\hline & 40 & 8.58 & -22.33 & & \\
\hline
\end{tabular}

\subsubsection{Comparative Study}

Compared with the sedimentary soil previously studied by our team was found that the adsorption capacity of different source of organic matter were different (Table 6). OTC adsorption capacity of humus soil was much larger than sedimentary soil [31]. This is verified by lower $1 / \mathrm{n}$ values and more negative $\Delta G$. It was also found the adsorption capacity of humus soil to OTC was reduced, and the adsorption capacity of sediment soil was increased after removing endogenous DOM. The reason for this may be that different types soil have different functional groups.

Table 6. Comparison of the OTC adsorption by different soil organic matter.

\begin{tabular}{|c|c|c|c|c|c|c|}
\hline \multirow{2}{*}{ Extraction Treatment of Sample } & \multicolumn{2}{|c|}{ Qe, exp (mg/kg) } & \multicolumn{2}{|c|}{$\begin{array}{l}\text { Freundlich Model } \\
\text { Parameter (1/n) }\end{array}$} & \multicolumn{2}{|c|}{$\begin{array}{c}\text { Thermodynamics } \\
\text { Parameter }\left(\Delta G, 40^{\circ} \mathrm{C}\right)\end{array}$} \\
\hline & $\begin{array}{l}\text { Sediments } \\
\text { Soil }\end{array}$ & $\begin{array}{l}\text { Humus } \\
\text { Soil }\end{array}$ & $\begin{array}{l}\text { Sediments } \\
\text { Soil }\end{array}$ & $\begin{array}{c}\text { Humus } \\
\text { Soil }\end{array}$ & $\begin{array}{l}\text { Sediments } \\
\text { Soil }\end{array}$ & $\begin{array}{c}\text { Humus } \\
\text { Soil }\end{array}$ \\
\hline Original soil & 111.50 & 842.10 & 0.6199 & 0.4469 & -8.48 & -19.33 \\
\hline Removal of DOM & 238.07 & 732.78 & 0.8386 & 0.4947 & -10.53 & -16.03 \\
\hline Removal of minerals & 60.28 & 553.14 & 0.7716 & 0.6364 & -5.16 & -12.80 \\
\hline
\end{tabular}




\subsection{Effects of External Factors}

\subsubsection{Effect of $\mathrm{pH}$ on Adsorption}

From Figure 4, we found the $\mathrm{pH}$ conditions can affect the adsorption of fractions other than HNHC. In general, OTC is amphoteric so that OTC exhibits different electrical properties at different $\mathrm{PH}$ values [41,42]. Furthermore, when the $\mathrm{pH}>\mathrm{pHzpc}$, the surface of the soil is negatively charged. On the contrary, the surface of soil surfaces is positively charged $[43,44]$. The pHzpc of different fractions was 5.12 5.65. When the $\mathrm{pH}$ is under 3.00, the dimethyl ammonium group was protonated and exists as an $\mathrm{OTCH}_{3}{ }^{+}$. The different fractions are positively charged. The decreases of adsorption capacity since the rejection of the charge reduces the contact of the OTC with different fractions. Similarly, when the $\mathrm{pH}$ is above 7.00, OTC exists as $\mathrm{OTCH}^{-}$or OTC ${ }^{2-}$ owing to the loss of protons and different fractions being negatively charged. Therefore, the adsorption capacity decreases. Between $\mathrm{pH} 3.3$ and 7.7, because of phenolic diketone moiety loss of proton, it exists as $\mathrm{OTCH}_{2}{ }^{0}$. DOM can affect the adsorption of OTC through hydrophobic partitioning, complexation, and hydrogen bonding. Hence, the effects of $\mathrm{PH}$ on HOS and HRDOM are consistent [45]. It has been known that the zero charge point of most aluminosilicate minerals is around $\mathrm{pH} 3.00$ [46]. Therefore, when the $\mathrm{pH}$ is lower than 3 , there is no longer electrostatic repulsion between HRM and OTC. Fatty acid, polysaccharides, and protein have lots of oxygenous functional groups, which can compete for adsorption sites [47,48]. Therefore, the adsorption amount of HRLF for OTC is higher than HRM.

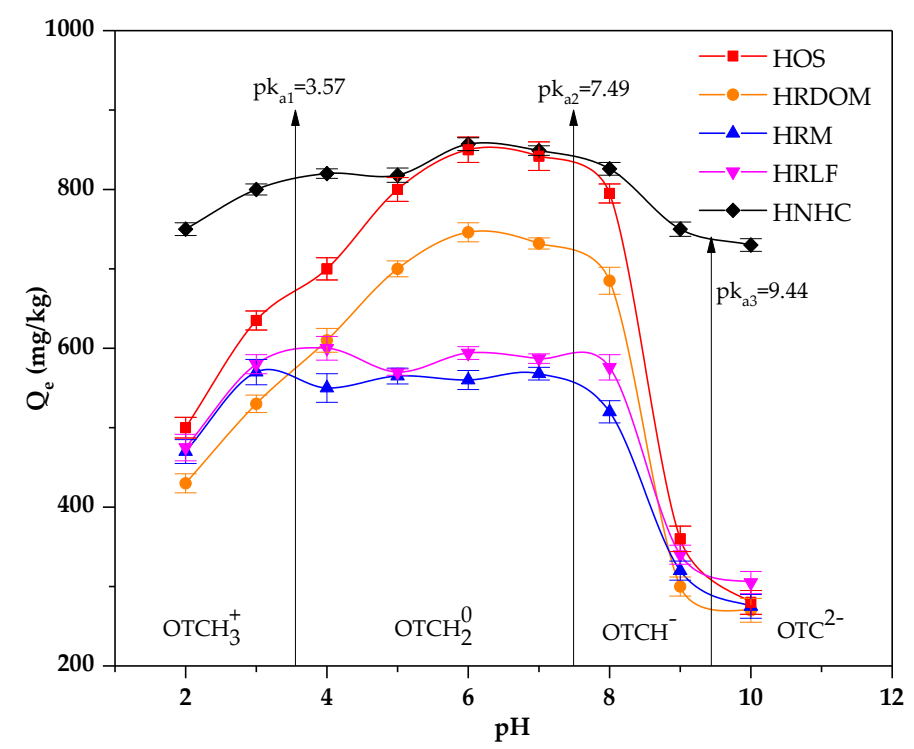

Figure 4. The effect of $\mathrm{pH}$ on the adsorption of OTC by different fractions.

\subsubsection{Effect of DOM on Adsorption}

Endogenous DOM in different types of soil has opposite effects on the adsorption of OTC. Adding two types of exogenous DOM into removal of endogenous DOM of humus (HR) and sedimentary soil (SR). The results are shown in Figure 5. It was reported that PDOM (from decay plant) mainly contains humic-like substances and MDOM (from chicken manure) mainly contains protein-like substances [49]. It can be seen that the presence of PDOM enhances the adsorption of soil to OTC in all concentrations. However, the adsorption capacity of OTC by two soils is decreased with the increasing MDOM concentration. 


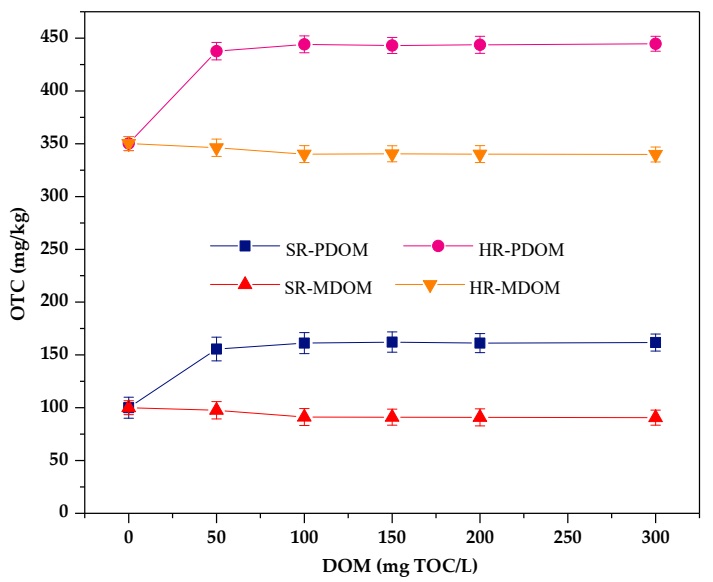

Figure 5. Effects of different DOM types on the adsorption of OTC in humus (HR) and sediment (SR) soil.

The location and meaning of fluorescence peaks are investigated by many studies (Figure 6) [50-55]. Different peaks of endogenous DOM extracted from humus and sedimentary soil can be identified by three-dimensional fluorescence spectra. The endogenous DOM of humus soil (Figure 6a) has a high strength $\mathrm{H} 3$ peak at $\mathrm{Ex} / \mathrm{Em}=340 / 430$, which is assigned to a lot of humic-like substances. Inversely, the endogenous DOM of sedimentary soil (Figure $6 b$ ) has two P2 peaks atEx/Em $=280 / 320$ and a high strength peak at $\mathrm{Ex} / \mathrm{Em}=230 / 320$, which are assigned to a lot of protein-like substances. Hence, the DOM of humus soli can promote the adsorption of OTC, while sedimentary soil does the opposite.

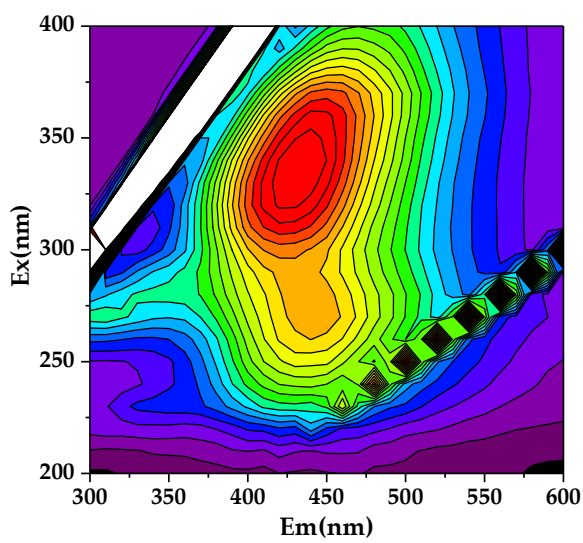

(a)
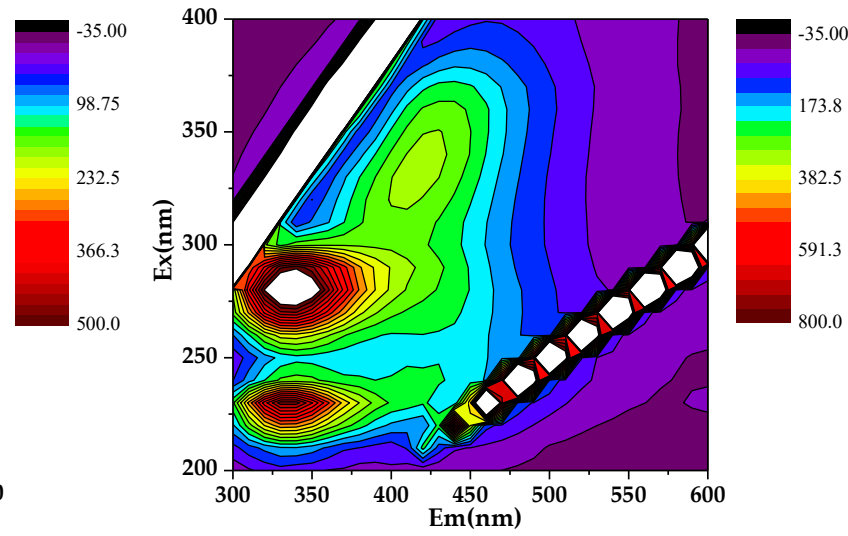

(b)

Figure 6. The 3D fluorescence spectra of DOM: (a) humus soil; (b) sedimentary soil.

\subsection{The Role of Internal Structure and Composition}

\subsubsection{Morphology and Specific Surface Area Characteristics}

The micro-structure of humus soil in different fractions of organic matter was recognized using SEM. Figure 7 shows the micro-structure features of HOS, HRDOM, HRLF, and HNHC with $10 \mu \mathrm{m}$ under 5000 times. It can be seen that HRDOM have a rougher surface and more microporous structure than HOS, while adsorption capacity is reduced. Although HRM have more pore structures generated after the removal of minerals, the adsorption capacity is the lower than other fractions. The number of pores of HRLF decreases, but the adsorption capacity increases, as opposed to HRM, which may be caused by more adsorption sites after the removal of free fat. The pore structure of HNHC almost disappeared and the surface is smooth, but the adsorption amount is much larger than other fractions. With the sequential removal of DOM, minerals, and free fat, more effective adsorption domains in 
HNHC were exposed, so the adsorption sites blocked or occupied become accessible for the adsorption of OTC. These phenomena indicated that the adsorption capacity of different fractions to OTC is not completely dependent on the rough surface and microporous structure. In order to further verify this conclusion, the different fractions of organic matter were determined by BET (Table 7, Figure 8).

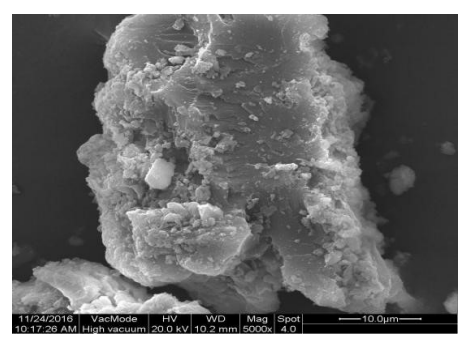

(a)

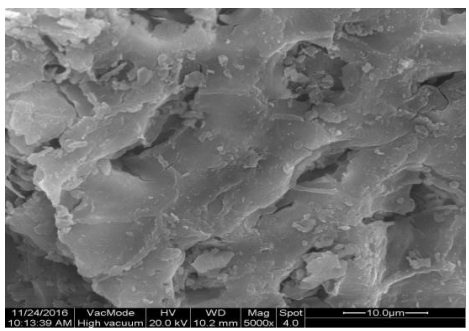

(d)

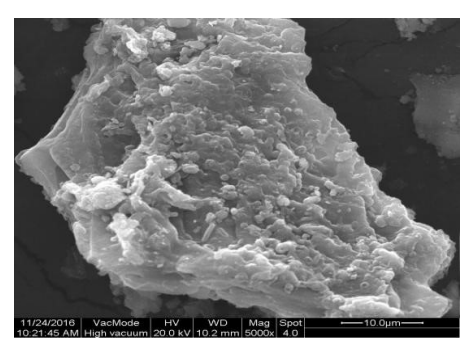

(b)

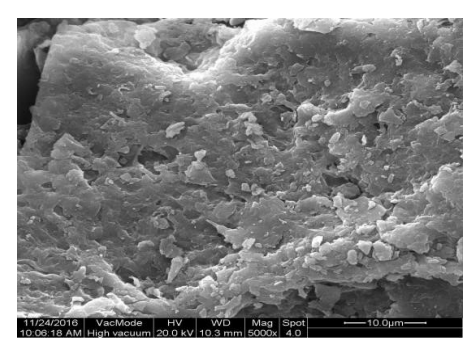

(c)

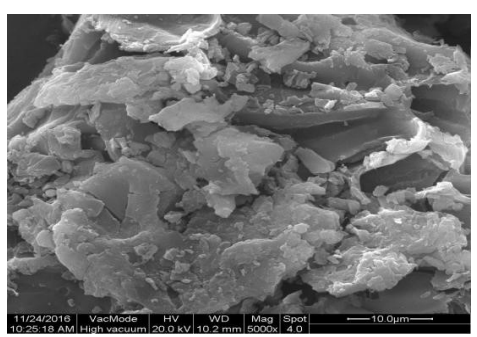

(e)

Figure 7. The micro-structure of: (a) HOS; (b) HRDOM; (c) HRM; (d) HRLF; (e) HNHC.

Table 7. Physical properties of different fractions.

\begin{tabular}{cccccc}
\hline sample & HOS & HRDOM & HRM & HRLF & HNHC \\
\hline $\begin{array}{c}\text { Surface Area } \mathrm{m}^{2} / \mathrm{g} \\
\begin{array}{c}\text { micropore volume } \\
\mathrm{cm}^{3} / \mathrm{g}\end{array}\end{array}$ & $-0.1983 \pm 0.2634$ & $0.5712 \pm 0.8463$ & $5.2148 \pm 3.2002$ & $137.5180 \pm 125.9391$ & $-0.3817 \pm 0.5365$ \\
\hline
\end{tabular}

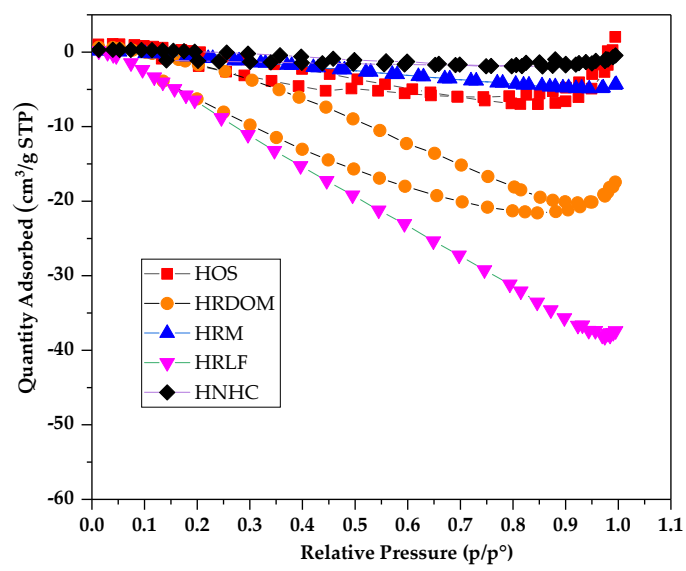

Figure 8. $\mathrm{N}_{2}$ adsorption-desorption isotherms of different fractions.

The organic matter of each fraction of the humus soil has a very smaller specific surface area than porous materials which have strong adsorption capacity. Among them, HRDOM, HRM, and HRLF are all undetected micropore volumes, while HOS and HNHC only have very small micropore volume. From Figure 8, the adsorption capacity of $\mathrm{N}_{2}$ by each fraction showed a downward trend 
as a whole. This is because the interaction between adsorbate molecules is stronger than between the adsorbate and adsorbent. It is further proven that a specific surface area of different fractions of organic matter are too small to purely physically adsorb. Except for HOS and HNHC showing a small amount of adsorption capacity under high relative pressure $\left(\mathrm{P} / \mathrm{P}^{0}\right)$, the remaining fractions have hardly the ability to physically adsorb OTC. It follows that the adsorption capacity is independent on the external structure. The adsorption capacity of different fractions of organic matter to OTC depends more on surface specific functional groups than surface area.

\subsubsection{Adsorption Site Distribution Characteristic}

The theory of site energy distribution can provide an adsorption amount of the adsorbent surface site and the corresponding fractional function [56]. The humus soil in various states based on Freundlich model is shown in Figure 9. According to the solubility of OTC, the relative adsorption energy $E^{*}$ values of OTC in the experimental concentration range are in the range of $16.758-31.851 \mathrm{~kJ} \cdot \mathrm{mol}^{-1}$.

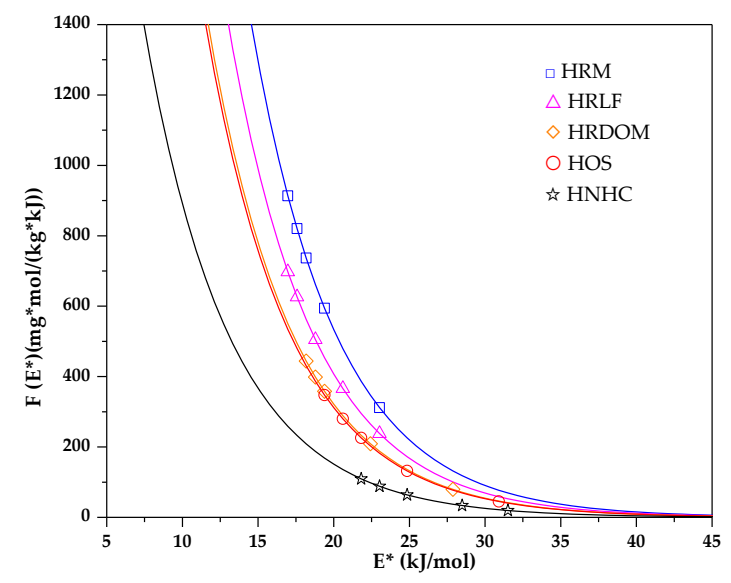

Figure 9. Site energy distribution based on adsorption isothermal model.

From Figure 9 it can be seen that the site energy distribution function decays rapidly by an exponential function. The adsorption sites of OTC in the HNHC fraction are distributed in the high energy region evenly, while the HRM and HRLF fractions are distributed in the low energy region evenly. In HOS and HRDOM fractions, the adsorption sites of OTC are distributed with a poor uniformity. The high energy adsorption sites of different fractions are covered by OTC in the low concentration range, thereby increasing the uniformity of surface organic matter. When adsorbed in a high concentration range, the organic matter of each fraction has a strong adsorption capacity for OTC, and there exist few high-energy adsorption sites. The adsorption process mainly occurs in the low energy region. Within a certain range, the area under the site energy distribution curve can be interpreted as the maximum number of sites available for adsorption. Therefore, OTC has more adsorption sites in the HNHC fraction, followed by HOS, HRDOM, HRLF, HRM. This indicates that the adsorption capacity of each fraction is ordered as: HNHC $>$ HOS $>$ HRDOM $>$ HRLF $>$ HRM. This result is in good accordance with the obtained data from the isothermal adsorption model.

\subsubsection{The Role of Functional Groups}

Before and after the adsorption of OTC, the changes of infrared spectra are shown in Figure 10. (1) The Si-O-Si stretching vibration peak of $872 \mathrm{~cm}^{-1}$ disappears or decreases in HOS and HRDOM samples, and the bending vibration peaks of Si-O in the vicinity of $790 \mathrm{~cm}^{-1}, 520 \mathrm{~cm}^{-1}$, and $460 \mathrm{~cm}^{-1}$ show displacement in different degrees, which indicates that the complexation or coordination may have occurred, and the interaction intensity of HOS and HRDOM are different; (2) For all fractions, the $\mathrm{C}-\mathrm{O}$ stretching vibration absorption peak is near $1020 \mathrm{~cm}^{-1}$ and the $\mathrm{C}=\mathrm{C}$ telescopic vibration peak located at $1600-1635 \mathrm{~cm}^{-1}$, while the shifts and vibration intensity also changed in different degrees. 
In other words, the charge transfer, coordination, or complexation with different effects are produced; (3) The O-H bending vibration peaks of HOS and HRDOM around $1400 \mathrm{~cm}^{-1}$ almost disappear in HOS and weakened in HRDOM, indicating that hydrogen bonding is occurred; (4) Owing to the association between the $-\mathrm{OH}$ molecules, which are named hydrogen bonds, the $-\mathrm{OH}$ near $3300 \mathrm{~cm}^{-1}$ stretching vibration absorption peak shifts downward and the peak shape of varied degrees of changes. The peak shape of HRM, HRLF, and HNHC become sharp significantly, showing that the intensity of hydrogen bonding between the fractions and OTC is different. Further, after OTC adsorption at each fraction, the peak intensity of the $400-1600 \mathrm{~cm}^{-1}$ region also changes, which further indicates the interaction with OTC molecules varied.

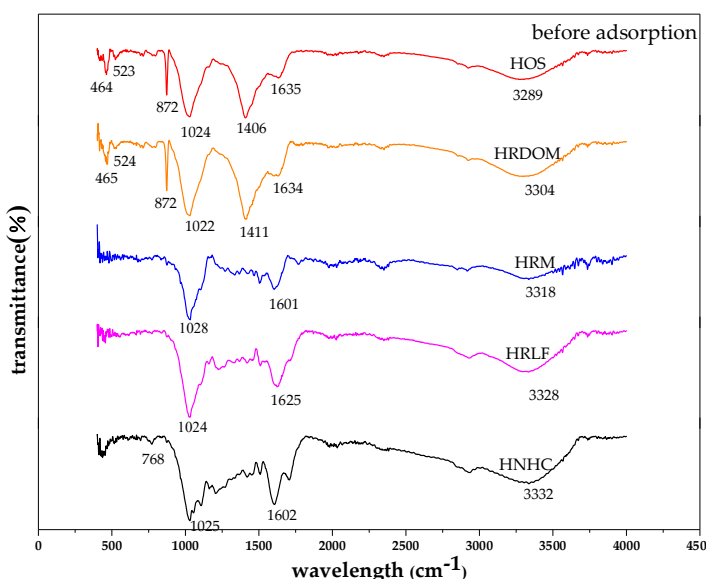

(a)

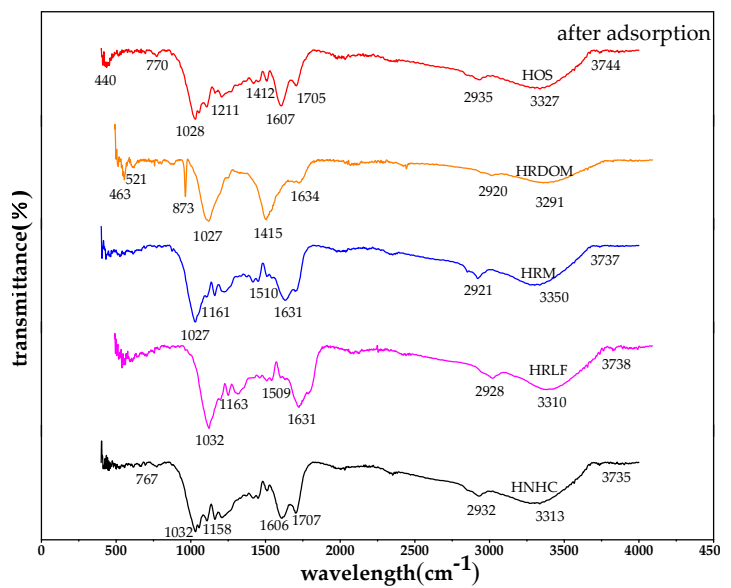

(b)

Figure 10. The infrared spectra of different fractions: (a) before adsorption; (b) after adsorption.

The atomic ratio about $\mathrm{H} / \mathrm{C},(\mathrm{N}+\mathrm{O}) / \mathrm{C}$ and $\mathrm{O} / \mathrm{C}$ indicate the aromatics, polarity, and hydrophilicity of different fractions, respectively (Table 8).

Table 8. Elemental composition of different humus fractions.

\begin{tabular}{cccccccccc}
\hline Samples & $\mathbf{C} \%$ & $\mathbf{H} \%$ & $\mathbf{N} \%$ & $\mathbf{O} \%$ & TOC $(\%)$ & $\mathbf{H} / \mathbf{C}$ & $\mathbf{O} / \mathbf{C}$ & $\mathbf{( N + O ) / C}$ & $\mathbf{K}_{\mathbf{d}}$ \\
\hline HOS & 26.05 & 3.19 & 1.95 & 30.81 & 28.96 & 1.47 & 0.89 & 0.95 & 381.20 \\
HRDOM & 27.03 & 3.40 & 1.73 & 32.39 & 24.06 & 1.51 & 0.90 & 0.95 & 194.48 \\
HRM & 47.06 & 4.70 & 2.92 & 39.72 & 47.43 & 1.20 & 0.63 & 0.69 & 67.05 \\
HRLF & 47.78 & 4.81 & 3.01 & 41.08 & 48.39 & 1.19 & 0.63 & 0.68 & 93.36 \\
HNHC & 49.23 & 4.24 & 1.75 & 38.18 & 49.32 & 1.03 & 0.58 & 0.61 & 425.59 \\
\hline
\end{tabular}

According to Figure 11 and Table 8, It can be seen that aromaticity, polarity and hydrophilicity all effect the adsorption capacity. For the fractions of HRM, HRLF, and HNHC based organic matter, the adsorption coefficient $\mathrm{K}_{\mathrm{d}}$ has a good positive correlation with aromaticity, while it has a negative correlation with polarity and hydrophilicity. HNHC has the largest adsorption capacity because of its highest aromaticity and lowest hydrophilicity and polarity. HOS and HRDOM have inorganic minerals which can influence adsorption. Therefore, although HOS and HRDOM have lower aromaticity and higher polarity than HRM, HRLF, and HNHC fractions, they still show a good adsorption capacity. 


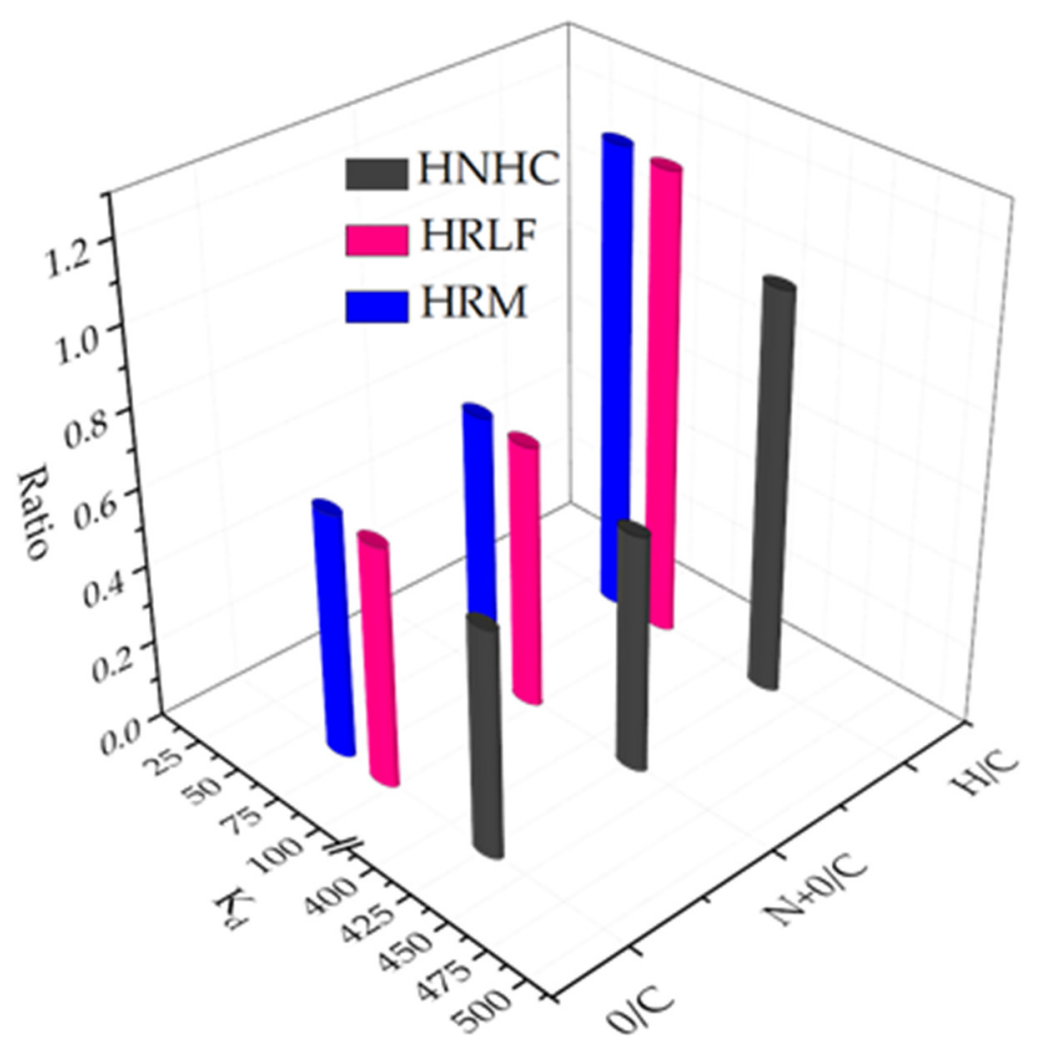

Figure 11. Relationship between adsorption coefficient $\mathrm{K}_{\mathrm{d}}$ of HRM, HRLF and HNHC and H/C, $(\mathrm{N}+\mathrm{O}) / \mathrm{C}, \mathrm{O} / \mathrm{C}$.

A schematic diagram for the binding affinity of aromatic, polar, and hydrophilic functional groups to OTC is established according to infrared spectra and elemental analysis (Figure 12). Using the sequential order rules, the sequence of functional groups in the interaction process of organic matter with OTC is in the order of the aromatic functional groups, i.e., $\mathrm{C}=\mathrm{C}$, phenolic and aliphatic $>$ the polarity groups, i.e., carboxyl and carbonyl $>$ the hydrophilic functional groups, i.e., hydroxyl and amino.

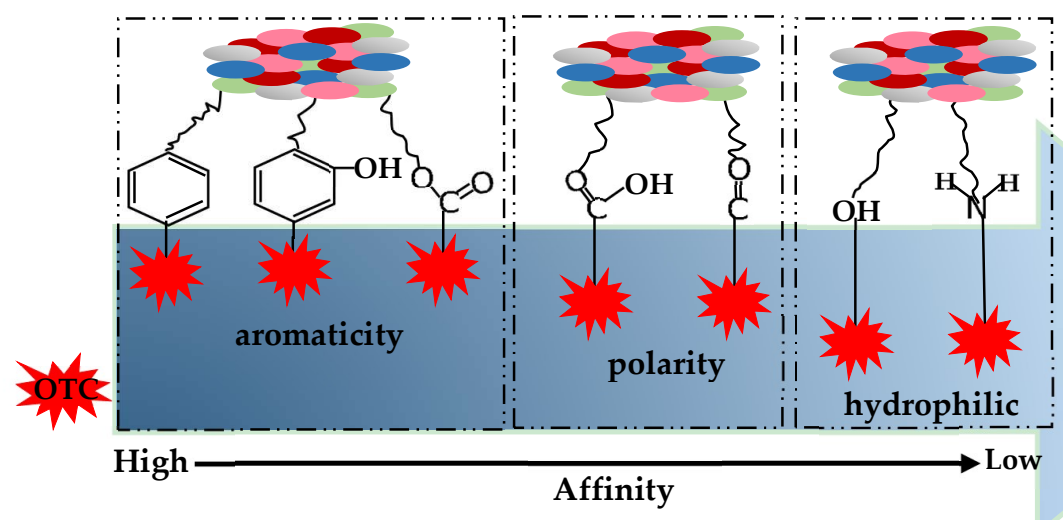

Figure 12. The affinity of functional groups combined with OTC.

This study is significant to control antibiotics migration to groundwater. However, due to pollutants in the environment such as antibiotics, heavy metals, and hydrophobic organic pollutants, it is necessary to further research composite pollutants adsorption feature by different fractions. 


\section{Conclusions}

This work identifies the relationship between humus soil organic matter and adsorption feature of OTC. The HNHC fraction has the largest adsorption capacity due to containing more aromatic functional groups than other fractions, and controls the fate of antibiotics in the soil environment. Therefore, it is one of the most important factors that must be paid attention to when studying the fate of antibiotics in soil. The following conclusions are drawn:

1. Sorting of adsorption capacity for each fraction as: HNHC $>$ HOS $>$ HRDOM $>$ HRLF $>$ HRM. This rule is verified by the theory of site energy distribution.

2. After removing the endogenous dissolved organic matter, the adsorption capacity of humus soil is decreased while sedimentary soil is increased. This is due to DOM in humus soil containing a large amount of humic-like substances, while the DOM in sedimentary soil contains a large amount of protein-like substances.

3. For the fraction based organic matter (HRM, HRLF and HNHC), the adsorption capacity has a positive correlation with aromaticity, while it has a negative correlation with polarity and hydrophilicity. The OTC affinity of corresponding functional groups is in the order of aromatic> polarity $>$ hydrophilic.

Author Contributions: Conceptualization, S.Y.; methodology, M.L.; formal analysis, M.L.; investigation, Y.L.; writing-original draft preparation, M.L.; writing-review and editing, S.Y.; supervision, S.S.; funding acquisition, S.Y. All authors have read and agreed to the published version of the manuscript.

Funding: This research was funded by the National Natural Science Foundation of China (grant number 41672224 and 41977163); National Key Research and Development Program of China (grant number 2016YFC0400701); The Provincial Natural Science Foundation of Shaanxi Province, China (grant number 2019JM-428).

Conflicts of Interest: The authors declare no conflict of interest.

\section{Abbreviations}

$\begin{array}{ll}\text { OTC } & \text { Oxytetracycline } \\ \text { Phen } & \text { Phenanthrene } \\ \text { HOS } & \text { Humus soil } \\ \text { HRDOM } & \text { Removal of dissolved organic matter } \\ \text { HRM } & \text { Removal of minerals } \\ \text { HRLF } & \text { Removal of free fat } \\ \text { HNHC } & \text { nonhydrolyzable organic carbon } \\ \text { FA } & \text { Fulvic acid } \\ \text { HA } & \text { Humic acid } \\ \text { HM } & \text { Humin } \\ \text { KC } & \text { kerogen graphitic } \\ \text { BC } & \text { black carbon } \\ \text { TOC } & \text { The total organic carbon } \\ \text { UPLC } & \text { ultra-performance liquid chromatography } \\ \text { PDOM } & \text { Dissolved organic matter from decay plant } \\ \text { MDOM } & \text { Dissolved organic matter from chicken manure }\end{array}$

\section{References}

1. Klaus, K. Antibiotics in the aquatic environment-a review-part ii. Chemosphere 2009, 75, 417-434. [CrossRef]

2. Sang, D.K.; Cho, J.; Kim, I.S.; Vanderford, B.J.; Snyder, S.A. Occurrence and removal of pharmaceuticals and endocrine disruptors in south korean surface, drinking, and waste waters. Water Res. 2007, 41, 1020-1021.

3. Sarmah, A.K.; Meyer, M.T.; Boxall, A.B.A. A global perspective on the use, sales, exposure pathways, occurrence, fate and effects of veterinary antibiotics (vas) in the environment. Chemosphere 2006, 65, 725-759. [CrossRef] [PubMed] 
4. Diaz-Cruz, M.S.; Lopez de Alda, M.J.; Barcelo, D. Environmental behavior and analysis of veterinary and human drugs in soils, sediments and sludge. Trend. Anal. Chem. 2003, 22, 340-351. [CrossRef]

5. Xia, K.; Bhandari, A.; Das, K.; Pillar, G. Occurrence and fate of pharmaceuticals and personal care products (ppcps) in biosolids. J. Environ. Qual. 2005, 34, 91. [CrossRef]

6. Paul, K.; Blackwell, P.A.; Boxall, A.B.A. Column studies to investigate the fate of veterinary antibiotics in clay soils following slurry application to agricultural land. Chemosphere 2005, 60, 497-507. [CrossRef]

7. Li, Y.W.; Wu, X.L.; Mo, C.H.; Tai, Y.P.; Xiang, L. Investigation of sulfonamide, tetracycline, and quinolone antibiotics in vegetable farmland soil in the pearl river delta area, southern china. J. Agr. Food. Chem. 2011, 59, 7268-7276. [CrossRef]

8. Huang, X.; Liu, C.; Li, K.; Feng, L.; Liao, D.; Lin, L.; Zhu, Z.F.; Jie, L. Occurrence and distribution of veterinary antibiotics and tetracycline resistance genes in farmland soils around swine feedlots in fujian province, china. Environ. Sci. Pollut. Res. Int. 2013, 20, 9066-9074. [CrossRef]

9. Heuer, H.; Schmitt, H.; Smalla, K. Antibiotic resistance gene spread due to manure application on agricultural fields. Curr. Opin. Microbiol. 2011, 14, 236-243. [CrossRef]

10. Garcia-Galan, M.J.; Diaz-Cruz, M.S.; Barcelo, D. Occurrence of sulfonamide residues along the ebro river basin: Removal in wastewater treatment plants and environmental impact assessment. Environ. Int. 2011, 37, 462-473. [CrossRef]

11. Luo, Y.; Xu, L.; Rysz, M.; Wang, Y.; Zhang, H.; Alvarez, P.J.J. Occurrence and transport of tetracycline, sulfonamide, quinolone, and macrolide antibiotics in the haihe river basin, china. Environ. Sci. Technol. 2011, 45, 1827-1833. [CrossRef] [PubMed]

12. Schmitt, H.; van Beelen, P.; Tolls, J.; van Leeuwen, C.L. Pollution-induced community tolerance of soil microbial communities caused by the antibiotic sulfachloropyridazine. Environ. Sci Technol. 2004, 38, 1148-1153. [CrossRef] [PubMed]

13. Figueroa, R.A.; Leonard, A.; MacKay, A.A. Modeling tetracycline antibiotic sorption to clays. Environ. Sci. Technol. 2004, 38, 476-483. [CrossRef] [PubMed]

14. Figueroa, R.A.; MacKay, A.A. Sorption of oxytetracycline to iron oxides and iron oxide-rich soils. Environ. Sci. Technol. 2005, 39, 6664-6671. [CrossRef]

15. Mackay, A.A.; Canterbury, B. Oxytetracycline sorption to organic matter by metal-bridging. J. Environ. Qual. 2005, 34, 1964. [CrossRef]

16. Wang, R.; Yang, S.; Fang, J.; Wang, Z.; Chen, Y.; Zhang, D.; Yang, C. Characterizing the interaction between antibiotics and humic acid by fluorescence quenching method. Int. J. Environ. Res. Public Health 2018, 15, 1458. [CrossRef]

17. Zhao, Y.; Gu, X.; Gao, S.; Geng, J.; Wang, X. Adsorption of tetracycline (tc) onto montmorillonite: Cations and humic acid effects. Geoderma 2012, 183-184, 12-18.

18. Kolz, A.C.; Say Kee, O.; Moorman, T.B. Sorption of tylosin onto swine manure. Chemosphere 2005, 60, $284-289$. [CrossRef]

19. Gu, C.; Karthikeyan, K.G.; Sibley, S.D.; Pedersen, J.A. Complexation of the antibiotic tetracycline with humic acid. Chemosphere 2007, 66, 1494-1501. [CrossRef]

20. Zhang, L.; Wang, S.; Jiao, L.; Li, Y.; Yang, J.; Zhang, R.; Feng, S.; Wang, J. Effects of organic matter content and composition on ammonium adsorption in lake sediments. Sci. Pollut. Res. Int. 2015, 23, 1-9. [CrossRef]

21. De Rebello, T.R.; Bortolozo, F.R.; Parron, L.M. Organic matter content in riparian areas of soil composed of woody vegetation and grass and its effects on pesticide adsorption. Int. J. Recyc. Organic Waste Agr. 2019, 8, 67-72. [CrossRef]

22. Pils, J.R.V.; Laird, D.A. Sorption of tetracycline and chlortetracycline on k- and ca-saturated soil clays, humic substances, and clay-humic complexes. Environ. Sci. Technol. 2007, 41, 1928-1933. [CrossRef] [PubMed]

23. Weber, W.J.; Huang, W.; Leboeuf, E.J. Geosorbent organic matter and its relationship to the binding and sequestration of organic contaminants. Colloid. Surface. A 1999, 151, 167-179. [CrossRef]

24. Pan, B.; Xing, B.S.; Liu, W.X.; Tao, S.; Lin, X.M.; Zhang, X.M.; Zhang, Y.X.; Xiao, Y.; Dai, H.C.; Yuan, H.S. Distribution of sorbed phenanthrene and pyrene in different humic fractions of soils and importance of humin. Environ. Pollut. 2006, 143, 0-33. [CrossRef] [PubMed]

25. Orecchio, S.; Mannino, M.R. Chemical speciation of polycyclic aromatic hydrocarbons in sediments: Partitioning and extraction of humic substances. Mar. Pollut. Bull. 2010, 60, 1175-1181. [CrossRef] [PubMed] 
26. Sun, K.; Ran, Y.; Yang, Y.; Xing, B. Sorption of phenanthrene by nonhydrolyzable organic matter from different size sediments. Environ. Sci.Technol. 2008, 42, 1961-1966. [CrossRef]

27. Ran, Y.; Sun, K.; Yang, Y.; Xing, B.; Zeng, E. Strong sorption of phenanthrene by condensed organic matter in soils and sediments. Environ. Sci Technol. 2007, 41, 3952-3958. [CrossRef] [PubMed]

28. Jin, J.; Sun, K.; Wang, Z.; Han, L.; Pan, Z.; Wu, F.; Liu, X.; Zhao, Y.; Xing, B. Characterization and phthalate esters sorption of organic matter fractions isolated from soils and sediments. Environ. Pollut. 2015, 206, 24-31. [CrossRef]

29. Pridvorev, N.I.; Dedov, A.V.; Verzilin, V.V.; Korolev, N.N. Nonhydrolyzable residue in humus of chernozems. Eurasian Soil Sci. 2006, 39, 403-409. [CrossRef]

30. Souza, S.O.; Silva, M.d.M.e.; Santos, J.C.C.; de Oliveira, L.C.; do Carmo, J.B.; Botero, W.G. Evaluation of different fractions of the organic matter of peat on tetracycline retention in environmental conditions: In vitro studies. J. Soils Sediments 2016, 16, 1764-1775. [CrossRef]

31. Zhang, D.; Yang, S.K.; Wang, Y.N.; Yang, C.Y.; Chen, Y.Y.; Wang, R.Z.; Wang, Z.Z.; Yuan, X.Y.; Wang, W.K. Adsorption characteristics of oxytetracycline by different fractions of organic matter in sedimentary soil. Environ. Sci. Pollut. Res. 2019, 26, 5668-5679. [CrossRef] [PubMed]

32. Gelinas, Y.; Prentice, K.M.; Baldock, J.A.; Hedges, J.I. An improved thermal oxidation method for the quantification of soot/graphitic black carbon in sediments and soils. Environ. Sci. Technol. 2001, 35, 3519. [CrossRef] [PubMed]

33. Hu, J.; Zhang, H.; Peng, P.A. Fatty acid composition of surface sediments in the subtropical pearl river estuary and adjacent shelf, southern china. Estuar. Coast. Shelf Sci. 2006, 66, 346-356. [CrossRef]

34. OECD. Adsorption-desorption using a batch equilibrium method. OECD 2000, 1, 1-44.

35. Stromer, B.S.; Woodbury, B.; Williams, C.F. Tylosin sorption to diatomaceous earth described by langmuir isotherm and freundlich isotherm models. Chemosphere 2018, 193, 912-920. [CrossRef] [PubMed]

36. Chen, Y.; Zhang, D. Adsorption kinetics, isotherm and thermodynamics studies of flavones from vaccinium bracteatum thunb leaves on nka-2 resin. Chem. Eng. J. 2014, 254, 579-585. [CrossRef]

37. Dang, W.; Zhang, J.; Nie, H.; Wang, F.; Tang, X.; Wu, N.; Chen, Q.; Wei, X.; Wang, R. Isotherms, thermodynamics and kinetics of methane-shale adsorption pair under supercritical condition: Implications for understanding the nature of shale gas adsorption process. Chem. Eng. J. 2020, 383, 1385-8947.

38. Mohamed Ali, W.; Salah, J.; Naceur, J. Ammonium biosorption onto sawdust: Ftir analysis, kinetics and adsorption isotherms modeling. Bioresource Technol. 2010, 101, 5070-5075. [CrossRef]

39. Yu, Y.; Zhuang, Y.Y.; Wang, Z.H.; Qiu, M.Q. Adsorption of water-soluble dyes onto modified resin. Chemosphere 2004, 54, 425-430. [CrossRef]

40. Li, Y.H.; Di, Z.; Ding, J.; Wu, D.; Luan, Z.; Zhu, Y. Adsorption thermodynamic, kinetic and desorption studies of pb2+ on carbon nanotubes. Water Res. 2005, 39, 605-609. [CrossRef]

41. Pankaj, K.; Giese, R.F.; Aga, D.S. Investigating the molecular interactions of oxytetracycline in clay and organic matter: Insights on factors affecting its mobility in soil. Environ. Sci. Technol. 2004, 38, 4097-4105. [CrossRef]

42. Chang, P.H.; Li, Z.; Jiang, W.T.; Jean, J.S. Adsorption and intercalation of tetracycline by swelling clay minerals. Appl. Clay Sci. 2009, 46, 27-36. [CrossRef]

43. Sakurai, K.; Ohdate, Y.; Kyuma, K. Potentiometric automatic titration (pat) method to evaluate zero point of charge (zpc) of variable charge soils. Soil Sci. Plant Nutr. 1989, 35, 89-100. [CrossRef]

44. Hendershot, W.H.; Singleton, G.A.; Lavkulich, L.M. Variation in surface charge characteristics in a soil chronosequence1. Soil Sci. Soc. Amer. J. 1979, 43, 387-389. [CrossRef]

45. Chen, K.L.; Liu, L.C.; Chen, W.R. Adsorption of sulfamethoxazole and sulfapyridine antibiotics in high organic content soils. Environ. Pollut. 2017, 231, 1163-1171. [CrossRef] [PubMed]

46. Chen, B.; Min, W.U.; Zhang, D.; Ning, P.; Zhong, Z.; Mao, Z. Research advance in sorption mechanisms of antibiotics in soil inorganic minerals. Chem. Ind. Eng. Prog. 2012, 31, 193-200. [CrossRef]

47. Jia, M.; Fang, W.; Bian, Y.; Xin, J.; Yang, S.; Kengara, F.O.; Xu, R.; Xin, J. Effects of ph and metal ions on oxytetracycline sorption to maize-straw-derived biochar. Bioresour. Technol. 2013, 136, 87-93. (In Chinese) [CrossRef]

48. Jia, M.Y.; Wang, F.; Bian, Y.R.; Yang, X.L.; Cheng gang, G.U.; Song, Y.; Jiang, X. Influencing factors of cu (2+) sorption to straw-derived biochar. Soils 2014, 46, 489-497. (In Chinese) [CrossRef] 
49. Wang, Z.Z.; Jiang, Q.L.; Wang, R.Z.; Yuan, X.Y.; Yang, S.K.; Wang, W.K.; Zhao, Y.Q. Effects of dissolved organic matter on sorption of oxytetracycline to sediments. Geofluids 2018, 2018, 1-12. [CrossRef]

50. Coble, P.G. Marine optical biogeochemistry: The chemistry of ocean color. Cheminform 2007, 38, 402-418. [CrossRef]

51. Stedmon, C.A.; Markager, S. Resolving the variability in dissolved organic matter fluorescence in a temperate estuary and its catchment using parafac analysis. Limnol. Oceanogr. 2005, 50, 686-697. [CrossRef]

52. Stedmon, C.A.; Markager, S. Tracing the production and degradation of autochthonous fractions of dissolved organic matter by fluorescence analysis. Limnol. Oceanogr. 2013, 50, 1415-1426. [CrossRef]

53. Jorgensen, L.; Stedmon, C.A.; Kragh, T.; Markager, S.; Middelboe, M.; Søndergaard, M. Global trends in the fluorescence characteristics and distribution of marine dissolved organic matter. Mar. Chem. 2011, 126, 139-148. [CrossRef]

54. Ishii, S.K.L.; Boyer, T.H. Behavior of reoccurring parafac components in fluorescent dissolved organic matter in natural and engineered systems: A critical review. Environ. Sci. Technol 2012, 46, 2006-2017. [CrossRef] [PubMed]

55. Stedmon, C.A.; Seredyńska-Sobecka, B.; Boe-Hansen, R.; Tallec, N.L.; Waul, C.K.; Arvin, E. A potential approach for monitoring drinking water quality from groundwater systems using organic matter fluorescence as an early warning for contamination events. Water Resh. 2011, 45, 6030-6038. [CrossRef] [PubMed]

56. Carter, M.C.; Kilduff, J.E.; Weber, W.J. Site energy distribution analysis of preloaded adsorbents. Environ. Sci. Technol. 1995, 29, 1773-1780. [CrossRef] [PubMed]

(C) 2020 by the authors. Licensee MDPI, Basel, Switzerland. This article is an open access article distributed under the terms and conditions of the Creative Commons Attribution (CC BY) license (http://creativecommons.org/licenses/by/4.0/). 